\title{
Eğitim Programları ve Öğretim Alanındaki Lisansüstü Öğrencilerin Lisansüstü Öğrenim Sürecine İlişkin Görüşleria
}

\author{
Fevzi Dursunn, $^{\mathrm{b}, \mathrm{c}}$, Veda Yar Yildırım ${ }^{\mathrm{d}}$
}

\section{Özet}

Araştırmanın amacı, EPÖ alanında öğrenim gören ve mezun olan öğrencilerin EPÖ alanına ilişkin değerlendirmelerinin incelenmesidir. Araştırmada nitel araştırma desenlerinden durum çalışması deseni kullanılmıştır. Araştırmanın çalışma grubunu EPÖ alanında lisansüstü öğrenim gören ve mezun olan 21 öğrenci oluşturmaktadır. Çalışma grubunda yer alan öğrencilerin seçiminde karma örnekleme kullanılmıştır. Araştırmanın veri toplama aracı olarak yarı yapılandırılmış görüşme formu hazırlanmıştır. Verilerin analizinde içerik analizi ve betimsel analiz birlikte kullanılmıştır. Veriler MAXQDA 2020 nitel analiz programıyla analiz edilmiştir. EPÖ lisansüstü öğrencileri eğitim programlarını dinamik, ayrıntılı ve sistematik bir süreç, eğitimle ilgili tüm süreçler ve program ögeleri ile ifade etmektedirler. Bu kapsamın tamamına program okuryazarlığı denilebilir. Öğrenciler lisansüstü programda öğrendiklerini uygulamaya taşıdıklarını ifade etmektedirler. Araştırmaya katılan öğrenciler lisansüstü eğitimi kişisel gelişim, mesleki kariyer ve akademik personel olma olarak değerlendirmektedirler.
Anahtar Kelimeler

Eğitim programları ve öğretim

Lisansüstü öğrenciler

Alg1

Makale Hakkında

Geliş Tarihi: 30.05.2020

Kabul Tarihi: 01.09.2020

Doi: 10.18026/cbayarsos.745499

\section{The Opinions of Graduate Students in The Field of Curriculum and Instruction on The Graduate Learning Process}

\begin{abstract}
The aim of the study is to examine the evaluations of students studying and graduating in the field of $\mathrm{CI}$ regarding the field of $\mathrm{CI}$. A case study pattern, one of the qualitative research patterns, was used in the research. The study group of the research consists of 21 students studying and graduating in the field of CI. Mixed sampling was used in the selection of students in the study group. A semi-structured interview form was prepared as the data collection tool of the research. Content analysis and descriptive analysis were used together in the analysis of the data. The data were analyzed with MAXQDA 2020 qualitative analysis program. CI graduate students express curricula with a dynamic, detailed and systematic process, all educational processes and curriculum elements. All of this scope can be called curriculum literacy. The students state that they carry into practice what they have learned in the postgraduate program. Students participating in the research evaluate postgraduate education as personal development, professional career, and academic staff.
\end{abstract}

Keywords

\footnotetext{
a Çalışma herhangi bir sempozyumda/konferansta bildiri olarak sunulmamış ya da bir proje/kurum tarafından desteklenmemektedir.

b İletişim Yazarı: vedayaryildirim@gmail.com

c Doç. Dr., Tokat Gaziosmanpaşa Üniversitesi Eğitim Fakültesi, ORCID ID: https://orcid.org/0000-0003-2103-8940

d Dr. Öğr. Üyesi, Kahramanmaraş Sütçü İmam Üniversitesi Eğitim Fakültesi, ORCID ID: https://orcid.org/0000-0002-2129-4189
} 


\section{Giriş}

Lisansüstü eğitim programları bilimsel sürecin bir adımıdır. Bu sürecin tüm yönleriyle ele alınması sürecin niteliği açısından önemli görülmektedir. 1950'lerde başlayan lisansüstü eğitim başlangıçta kürsü sisteminde usta-çırak ilişkisi biçiminde devam ederken, 1981 yılından itibaren yüksek lisans, doktora, tıpta uzmanlık ve sanatta yeterlik başlıklarında yeni bir düzenleme yapılmış (Sağlam, 2007) ve daha sonra enstitülerin sorumluluğunda devam etmiştir.

Türkiye'de lisansüstü öğretim, lisans eğitimine dayalı olan yüksek lisans ve doktora eğitimiyle sanat dallarında yapılan sanatta yeterlik çalışması ve tıpta uzmanlıkla bunların gerektirdiği eğitim-öğretim, bilimsel araştırma ve uygulama etkinliklerinden oluşmaktadır. Lisansüstü Eğitim ve Öğretim Yönetmeliği'ne (2016) göre;

“Tezli yüksek lisans programı öğrencinin bilimsel araştırma yöntemlerini kullanarak bilgilere erişme, bilgiyi derleme, yorumlama ve değerlendirme yeteneğini kazanmasını sağlar. Tezsiz yüksek lisans programı, öğrenciye mesleki konularda bilgi kazandırarak mevcut bilginin uygulamada nasıl kullanılacağını gösterir. Doktora programı, öğrenciye bağımsız araştırma yapma, bilimsel problemleri, verileri geniş ve derin bir bakış açısı ile irdeleyerek yorum yapma, analiz etme ve yeni sentezlere ulaşmak için gerekli becerileri kazandırır" (Lisansüstü Eğitim ve Öğretim Yönetmeliği, 2016).

Lisansüstü öğretim, maliyetli ve zor bir süreçtir. Bu eğitim, toplumların gerek duyduğu bilim insanı yetiştiren programlı bir eğitim (Bülbül, 2003), bilgiyi üst düzeye çıkaran ve ihtisaslaşmayı sağlayan bir öğretim programıdır (Çakar, 2001). Bu anlamda lisansüstü eğitim programları planlı etkinlikler bütünüdür (Karakütük, 2001). Bu önemli ve planlı öğretim kademesinin birtakım sorunları da bulunmaktadır.

Duan ve Shan (2013) lisansüstü eğitimle ilgili sorunları akademik, örgütsel (kurumsal) ve kişisel olarak üç bölüme ayırmaktadır. Abiddin ve İsmail'in (2011) araştırmasına göre lisansüstü eğitim gören öğrencilerin bir yandan çalıştıkları, bir yandan aileleriyle ilgilenmeleri, yeterli bilgilendirme yapılmaması yüzünden eğitimi ya yarıda bırakmakta ya da eğitim uzamaktadır. Bu araştırmayı destekleyen bir başka araştırma Kayıkçı ve Ercan (2013) tarafından yapılmıştır. Araştırma sonucunda öğrenciler tayin, öğretim üyelerinin ilgisizliği ve ailesel nedenlere bağlı olarak eğitimlerini yarıda bırakmışlardır. Bu sorunların dışa vurumu olsa gerek ki Gömleksiz ve Et'in (2013) öğretmen adaylarıyla yaptığı çalışmada lisansüstü programa ilişkin geliştirilen metaforlar arasında kayırmacılık, baskı, sindirme, yanılgı ve umutsuzluk kavramları yer almaktadır. Bu araştırmada Eğitim Programları ve Öğretim (EPÖ) lisansüstü programına ilgili literatür ve bu programda lisansüstü öğrenim gören ve mezun olan öğrenciler açısından bakılmıştır.

EPÖ alanının tarihsel sürecine ve kapsamına ilişkin ilgili literatür incelendiğinde, eğitim bilimlerinde lisansüstü eğitim 1960'lı yılların sonunda Ankara Üniversitesi'nde başladığ görülmektedir. Ankara Üniversitesi'nde Eğitim Bilimleri Fakültesi'nde “Eğitim Programları ve Öğretim (EPÖ)" bilim dalı kurulduktan sonra, önce lisans düzeyinde daha sonra lisansüstü kademede eğitime başlanan bilim dallarından biri olmuştur (Bıkmaz, Aksoy, Tatar ve Atak, 2013). Kurulduğu dönemde EPÖ alanının amacı Kavcar (1976:31; akt. Bıkmaz vd, 2013) tarafından şöyle ifade edilmiştir: "Eğitim sorunlarına, mukayeseli eğitim, çocukların ve gençlerin öğretiminde uyulacak ilke, metot ve teknikler ile çeşitli kademelere rehberlik etmesi beklenen 
programlarm geliştirilmesine ilişkin alanlarda perspektif kazandıran derslere ve faaliyetlere lisans ve lisansüstü düzeyde yer vermek".

Kurulduğu dönemden bugüne EPÖ alanının amacını karşılaştırmak için bugün EPÖ alanının amaçları incelendiğinde; Bologna süreci kapsamında EPÖ alanının amac1, hedefi ve yeterlikleri Kahramanmaraş Sürçü İmam Üniversitesi (KSÜ) Sosyal Bilimler Enstitüsü EPÖ yüksek lisans programında şu şekilde yer almaktadır:

“EPÖ Yüksek Lisans programının amacı; bilginin doğasının anlamlı bir biçimde yapılandırılmasını sağlayacak eğitim programlarının geliştirilmesi ve değerlendirilmesine rehberlik edecek; etkili öğretme-öğrenme süreçlerini tasarlayabilen, üst düzey düşünme becerilerine sahip; bilimsel araştırma yöntem ve ilkelerini yaşamının her alanında işe koşabilen yaşam boyu öğrenen bireyler yetiştirmektir. EPÖ bilim dalı; gerek, kamu ve özel kurum /kuruluşlardaki örgün ve yaygın eğitimi planlamak ve yürütmek üzere program geliştirme uzmanı ihtiyacını karşılamakta gerekse eğitim fakültelerinde program geliştirme ve öğretim ile alan öğretiminde görev yapacak öğretim elemanlarını yetiştirmektedir. Bu programın başarılı bir şekilde tamamlanmasıyla öğrenciler; eğitim bilimlerindeki yeni gelişmeleri, öğrenme-öğretme kuram ve modellerini açıklayabilecek, öğretim yöntem ve tekniklerini, Türk eğitim sistemini, eğitim araştırmalarındaki yeni problemleri tanıyabilecek, eğitim programlarını karşılaştırabilecek, eğitim bilimleri konularında öğrendiklerini uygulayabileceklerdir (www.ksu.edu.tr).

Görüldüğü üzere EPÖ alanının amacı tarihsel süreçte de değişmeden benzer şekilde devam etmektedir.

Amaçlarından biri program geliştirme olan EPÖ alanının yüklendiği misyon oldukça önemlidir. Çünkü program geliştirmede asıl hedef çocukları içinde bulunduğu çoklu etkileşimli çağ olan 21. yüzyıla ve geleceğe hazırlamaktır (IBE, 1998, s. 2). Tarihsel olarak bakıldığında eğitim programlarına iki farklı görüş bulunmaktadır. Bunlardan birincisi, F. Bobbitt'in yazmış olduğu "The Curriculum" (Eğitim Programı) adlı kitapla eğitim programları kavramı kullanılmaya başlamıştır (Korkmaz, 2007). Diğer bir görüşe göre ise M.Ö. I yüzyılda Roma askerlerinin yarış arabalarının yarıştığı pistin üzerinde curiculum yazmakta ve koşu yolu anlamında kullanılmaktadır. Bu kavram zamanla eğitim programı, izlenen yol anlamında eğitimde de kullanılmaya başlamıştır (Demirel, 2005). Bu kavram bireylere öğrenme yaşantıları kazandırma planı olarak da (Saylor, Alexander ve Lewis, 1981, s. 8) tanımlanmaktadır ki, tam da bugün eğitimde duyulan ihtiyacı belirtmektedir. Çünkü eğitim programı geliştirmenin amacı, sistemde kaliteli, nitelikli insan gücünü yetiştirme, kültürel değerlerin korunmasıdır (Özdemir, 2009).

Eğitim programları eğitim sisteminde yetiştirilecek insanın nasıl olması gerektiğini içermektedir. Bu insanın yetiştirilmesi için öğrenme durumlarını, yaşantıları, yöntem, tekniği, değerlendirmeyi, kullanılacak materyalleri belirler. Eğitim programlarının uygulayıcıları da öğretmenlerdir. Öğretmenlerin programa hakkındaki algıları önemlidir. Çünkü insanı algısı (paradigması) yönetmektedir. Öğretmen adayları üzerine yapılan bir araştırmada eğitim programına ilişkin; "sistemli bir bütün, rehber, kilometre taşı" gibi olumlu metaforlar üretirlerken, "sorun yaratan karmaşık yapı" şeklinde olumsuz metafor da ürettikleri görülmektedir (Gültekin, 2013) 
Yükseköğretim Kurulu (YÖK), EPÖ lisans programlarını 1997 yılında kapatmıştır. Son mezun 2000 yılında verilmiştir. Lisans mezunları Millî Eğitim Bakanlığı'nda ve diğer kamu, özel kurumlarda "eğitim uzmanı" unvanıyla istihdam edilmişlerdir (Gözütok, Alkın ve Uluğbey, 2010). 1997 yılında EPÖ bilim dalının lisansüstü eğitimde yüksek lisans ve doktora düzeyinde eğitim vermesi öngörülmüştür (Erişti, 2013). Türkiye'de EPÖ lisansüstü programlarında açılan dersler birbirine benzemektedir. Bazı farklılıklarla birlikte programda şu dersler verilmektedir: Eğitimde program geliştirme ve değerlendirme, bilimsel araştırma, karşılaştırmalı eğitim, Türk Eğitim Sistemi, öğrenme yaklaşımları, öğretmen eğitimi (Bıkmaz ve İşcan, 2012).

Lisansüstü eğitime alanda eğitim gören öğrenciler gözünden incelendiğinde, lisansüstü eğitimde birçok sorun görülmektedir. Bu sorunlar öğretim üyesine, mali konulara, kütüphane hizmetlerine, yabancı dile, yönetsel alana, tez danışmanına, araç gerece ilişkin sorunlar (Karaman ve Bakırcı, 2010) şeklindedir. Sınıf öğretmenliği doktora mezunlarının; programı tam anlamıyla içerecek derslerin eksikliği, süreç değerlendirme eksikliği, bilimsel araştırma derslerinin yetersizliği konularında eleştirileri bulunmaktadır (Gültekin ve Dal, 2007).

Güven, Kerem ve Ersoy'un (2007) araştırmasına göre lisansüstü öğrenciler, derslerin içeriklerinin, akademisyen yeterliklerinin, akademisyenlerle öğrenciler arasında sağlıklı iletişimin ve akademisyenlerin danı̧̧manlık yeterliklerinin çok önemli olduğunu belirtmektedirler. Burgaz ve Şentürk'ün (2007) yapmış oldukları araştırmada lisansüstü öğrenciler, olması gereken danışman özellikleri açısından kendi danışmanlarında bu özelliklerin tam da olmadığı yönünde görüş bildirmişlerdir. Dünyada da bu durum benzer görülmektedir. Myers ve Dyer'in (2003) araştırma sonucunda da katılımcıların çoğu aldıkları danışmanlık hizmetinin yetersiz olduğunu belirtmektedirler. Diğer taraftan, EPÖ bölümündeki öğretim üyeleri lisansüstü öğrencilerini eğitim bilimleri altyapısı konusunda yetersiz olarak değerlendirmektedirler (Gözütok, Alkın ve Ulubey, 2010).

$\mathrm{Bu}$ araştırmada EPÖ alanında lisansüstü öğrenim gören ve mezun olan öğrencilerin alana bakışları incelenmiştir. Kendilerini ve alanı nasıl gördüklerinin süreci yaşayanlar tarafından incelenmesi önemli görülmektedir. Yukarıda ilgili literatür ışı̆̆ında lisansüstü eğitim ve EPÖ alanına ilişkin verilerden sonra araştırmanın amac1; EPÖ alanında öğrenim gören ve mezun olan öğrencilerin programa ilişkin değerlendirmelerinin incelenmesidir. Bu amaçla aşağıdaki sorulara cevap aranmiştır:

a. EPÖ lisansüstü öğrencilerinin eğitim programlarına ilişkin çağrışımları nelerdir?

b. EPÖ lisansüstü öğrencilerinin eğitim programları ve öğretim alanı hakkında bilgi düzeyleri ve yeterlikleri hakkında düşünceleri nelerdir?

c. EPÖ lisansüstü öğrencilerinin EPÖ alanında lisansüstü eğitim yapmalarının nedenleri nelerdir?

d. EPÖ lisansüstü öğrencilerinin EPÖ alanında lisansüstü eğitim yapmalarının kendilerinde oluşturduğu memnuniyet ve memnuniyetsizlik nedenleri nelerdir?

e. EPÖ lisansüstü öğrencilerine göre EPÖ alanında lisansüstü eğitim yapanların görev alanları nelerdir?

f. EPÖ lisansüstü öğrencilerine göre EPÖ alanındaki araştırma konuları neler olabilir? 


\section{Yöntem}

Bu bölümde araştırmanın modeli, çalışma grubu, veri toplama aracının geliştirilmesi ve toplanması, verilerin analizi bölümlerine yer verilmektedir.

\section{Araştırmanın Modeli}

Bu araştırmada EPÖ bilim dalında lisansüstü öğrenim gören ve mezun olan öğrencilerin alana ilişkin düşünceleri nitel araştırma desenlerinden durum çalışması deseni kullanılarak incelenmiştir "Durum çalışması "nasıl" ve "niçin" sorularını temel alan, araştırmacının kontrol edemediği bir olgu ya da olayı derinliğine incelemesine olanak veren araştırma yöntemidir" (Yıldırım ve Şimşek, 2011; s. 277).

\section{Çalışma Grubu}

Araştırmanın çalışma grubunu EPÖ alanında lisansüstü öğrenim gören ve mezun olan 21 katılımcı oluşturmaktadır. Çalışma grubunda yer alan öğrencilerin seçiminde karma örnekleme kullanılmıştır. Karma örnekleme bilgi yüklü durumların seçilmesi için kullanılabilir (Charmaz, 2011, akt. Baltacı, 2018). Bu amaçla araştırmada ölçüt ve maksimum çeşitlilik örnekleme yöntemleri kullanılmıştır. Maksimum çeşitlilik örneklemesinde amaç görüşülen gurupta çeşitliliği artırmaktır. Bunun için görüşülen öğrencilerin öğrencilik aşaması, branş, cinsiyet, görev yaptığı kuruma dikkat edilmiştir. Araştırmada kullanılan diğer bir örnekleme ölçüt örneklemedir. Ölçüt örnekleme, önceden belirlenmiş bir dizi ölçütü karşılayan bütün durumların çalışılmasıdır (Baltacı, 2018). Bu araştırmada belirlenen ölçüt, öğrencilerin EPÖ bilim dalında ve en az yüksek lisans tez aşamasında olmalarıdır. Araştırma kapsamında görüşülen öğrencilere ilişkin bilgiler Tablo 1'de verilmektedir:

\section{Çalışma Grubu}

Tablo 1. Çalışma Grubuna İlişkin Veriler

\begin{tabular}{lllllll}
\hline S.N. & Cinsiyet & Yaş & Eğitim Aşama & Kıdem & Görev & Lisans \\
\hline 1 & Erkek & 38 & Doktora Tez & $4 / 1,18$ Yıl & Öğretim Gör. & Sınıf \\
2 & Erkek & 31 & Y.Lis. Tez & $6 / 1$ & Öğretmen & İngilizce \\
3 & Erkek & 35 & Doktora Tez & 12 & Araş. Gör & İngiliz Dili \\
4 & Kadın & 33 & Doktora Tez & $3 / 1$ & Öğretim Gör. & Sınıf \\
5 & Erkek & 31 & Y.Lis. Tez & - & Öğretmen & Türkçe \\
6 & Kadın & 31 & Doktora Tez & 9 & Öğretmen & İngilizce \\
7 & Erkek & 29 & Doktora Tez & 8 & Araş. Gör. & İngilizce \\
8 & Kadın & 29 & Y.Lis. Tez & - & Öğretmen & İngilizce \\
9 & Kadın & 35 & Doktora Yeterlik & 2 & Öğretim Gör. & Matematik \\
10 & Erkek & 32 & Y.Lis. Tez & 9 & Öğretmen & Sınıf \\
11 & Erkek & 41 & Doktora Tez & 19 & Öğretmen & Aile Ekon. \\
12 & Erkek & 32 & Y.Lis. Tez & - & Öğretmen & İngilizce \\
13 & Erkek & 35 & Y.Lis. Tez & $3 / 1$ & Öğretmen & İngilizce \\
\hline
\end{tabular}




\begin{tabular}{lllllll}
\hline 14 & Kadın & 29 & Y.Lis. Tez & 8 & Öğretmen & İngilizce \\
15 & Kadın & 32 & Doktora Tez & 9 & Okutman & İngilizce \\
16 & Kadın & 28 & Doktora Tez & 4 & Araş. Gör. & Matematik \\
17 & Erkek & 37 & Doktora Tez & 16 & Öğretmen & Bilişim Tek. \\
18 & Kadın & 36 & Y.Lis. Tez & 5 & Öğretmen & İngilizce \\
19 & Kadın & 35 & Doktora Mezun & 12 & Öğretmen & İngilizce \\
20 & Kadın & 33 & Doktora Tez & 11 & Öğretmen & İngilizce \\
21 & Kadın & 28 & Doktora Tez & 5 & Araş. Gör. & İngilizce \\
\hline
\end{tabular}

Tablo 1'de görüldüğü gibi araştırmanın çalışma grubu EPÖ alanında lisansüstü öğrenim gören ve mezun olan 21 öğrenciden oluşmaktadır. Bunların 10'u erkek, 11'i kadındır. Çalışma grubunda yüksek lisans tez dönemi, doktora tez dönemi ve mezunu olmak üzere lisans üstü eğitimin farklı aşamalarından katılımcı bulunmaktadır. Katılımcıların daha çok İngilizce öğretmenliği lisans alanı mezunu oldukları görülmektedir.

\section{Veri Toplama Aracının Geliştirilmesi ve Verilerin Toplanması}

Araştırmanın veri toplama aracı olarak yarı yapılandırılmış görüşme formu hazırlanmıştır. Form hazırlanmadan önce lisansüstü eğitim ve EPÖ bilim dalına ilişkin ilgili literatür taranmıştır. Eğitim programları ve öğretim anabilim dalında çalışan iki ve eğitim yönetimi ana bilim dalında çalışan bir öğretim üyesinden geliştirilen form için uzman görüşü alınmıştır. Görüşme formu iki bölümdür. Birinci bölümde araştırmaya katılan öğrencilere ilişkin demografik bilgiler, diğger bölümde de EPÖ bilim dalına ilişkin sorular yer almaktadır.

\section{Verilerin Analizi}

Verilerin analizinde içerik analizi ve betimsel analiz birlikte kullanılmıştır. İçerik analizi yapılırken önce öğrenciler görüşme sırasına göre numaralandırılmıştır (G1, G2, ..). Veriler kodlanmış ve belirli temalar altında birleştirilmiştir. Analiz süresince görüşler tekrar edilme sıklığına (f) göre en çoktan en aza doğru sıralanarak yorumlanmıştır. Araştırma kapsamında geçerlik çalışması için uzman görüşlerine yer verilmiştir.

Araştırmanın iç güvenirliğini sağlamak için ise; öncelikle araştırmanın tüm süreçleri (literatür tarama, görüşme formunun hazırlanması, uygulama, analiz) detaylarıyla açıklanmıştır. İkinci olarak araştırmanın sonuçları, araştırmaya katılan bireylerle paylaşılarak onların görüşleri alınmıştır. Son olarak aynı alanda yapılan diğer çalışmaların sonuçlarıyla karşılaştırılmıştır (Yıldırım ve Şimşek, 2011). Verilerin analizi MAXQDA 2020 programıyla yapılmıştır.

\section{Bulgular}

Bu bölümde çalışmanın amaçları doğrultusunda EPÖ lisansüstü öğrencilerinin görüşlerine ilişkin yapılan analiz sonuçlarına dair bulgulara yer verilmiştir.

\section{EPÖ Lisansüstü Öğrencilerinin Ĕ̆itim Programlarına İlişkin Çă̆rışımları}

Araştırma örnekleminde yer alan EPÖ lisansüstü öğrencilerinin eğitim programlarıyla ilgili çağrışımlarına dair tema ve kodlar Tablo 2' de verilmiştir. 
Tablo 2. Lisans Üstü Öğrencilerinin “Eğitim Programı” Çağrışımlarına Dair Bulgular

\begin{tabular}{|c|c|c|c|c|}
\hline No & Tema & Kod & $\mathbf{f}$ & $\%$ \\
\hline \multirow[t]{2}{*}{1} & Eğitim & Eğitimle ilgili tüm süreçler & 13 & $\% 17,3$ \\
\hline & $(\mathrm{f}=19, \% 25,3)$ & Eğitimin niteliğinin artması & 6 & $\% 8,0$ \\
\hline \multirow[t]{3}{*}{2} & Eğitim programı tanımı & Farklı eğitim programı tanımları & 8 & $\% 10,7$ \\
\hline & $(\mathrm{f}=16, \% 21,3)$ & Dinamik bir süreç & 5 & $\% 6,7$ \\
\hline & & Ayrıntıl1- sistematik bir süreç & 3 & $\% 4$ \\
\hline \multirow[t]{8}{*}{3} & Programa dair & Eğitim programının amacı & 5 & $\% 6,7$ \\
\hline & $(\mathrm{f}=16, \% 21,3)$ & Değişiklikler & 3 & $\% 4$ \\
\hline & & Bölüm dersleri & 2 & $\% 2,7$ \\
\hline & & İhtiyaç & 2 & $\% 2,7$ \\
\hline & & Eğitim programları ve öğretim & 1 & $\% 1,3$ \\
\hline & & Program geliştirme & 1 & $\% 1,3$ \\
\hline & & Öğretim programları & 1 & $\% 1,3$ \\
\hline & & Cumhuriyet dönemi eğitim programları & 1 & $\% 1,3$ \\
\hline \multirow[t]{4}{*}{4} & Program ögelerine dair & Programın ögeleri & 8 & $\% 10,7$ \\
\hline & $(\mathrm{f}=14, \% 18,7)$ & Ögelerin tanımları & 3 & $\% 4$ \\
\hline & & Hedef & 2 & $\% 2,7$ \\
\hline & & Ögeler arası ilişki & 1 & $\% 1,3$ \\
\hline \multirow[t]{2}{*}{5} & Farklı isimlendirmeler & Rehber-kılavuz & 6 & $\% 8,0$ \\
\hline & $(\mathrm{f}=8, \% 10,7)$ & Literatürdeki diğer isimler & 2 & $\% 2,7$ \\
\hline \multirow[t]{3}{*}{6} & Olumsuz & Yetiştirilmesi gerek konular listesi & 1 & $\% 1,3$ \\
\hline & $(\mathrm{f}=2, \% 2,7)$ & Başarısızlık & 1 & $\% 1,3$ \\
\hline & & Toplam & 75 & $\% 100$ \\
\hline
\end{tabular}

Tablo 2 incelendiğinde, EPÖ lisansüstü öğrencilerinin eğitim programlarına dair çağrışımları 6 temada (eğitim, eğitim programı tanımı, programa dair, programın ögelerine dair, farklı isimlendirmeler, olumsuz) toplanmakta ve bu temaların toplam görüş sayısının 75 olduğu görülmektedir.

Bulgular genel olarak incelendiğinde, lisansüstü öğrencilerinin çağrışımlarının en çok eğitim $(\mathrm{f}=19, \% 25,3)$, eğitim programı tanımı $(\mathrm{f}=16, \% 21,3)$, programa dair $(\mathrm{f}=16, \% 21,3)$ ve program ögelerine dair ( $\mathrm{f}=14, \% 18,7)$ temalarında toplandığ1 görülmektedir. Lisansüstü öğrencileri eğitim programları denildiğinde "eğitim" temasında ve bütün kodlar içinde en çok "Eğitimle ilgili tüm süreçleri ( $\mathrm{f}=13, \% 17,3)$ " işaret eden görüşler belirtmişlerdir.

Eğitim programları denildiğinde lisansüstü öğrencilerinin ifadelerinin ikinci en sık olarak “Eğitim programı tanımı (f=16, \%21,3)" temasında toplandığı ve öğrencilerin bu temada en çok 
“Farklı eğitim programı tanımları $(\mathrm{f}=8, \% 10,7)$ ” yaptıkları görülmüştür. Bu tanımlar genel olarak literatürde geçen klasik eğitim programı tanımlarına benzerlik göstermektedir. EPÖ lisansüstü öğrencileri eğitim programları denildiğinde "dinamik bir süreç $(f=5, \% 6,7)$ " ve “ayrıntıl1- sistematik bir süreç ( $\mathrm{f}=3, \% 4)$ " şeklinde vurgu da yapmışlardır.

EPÖ lisansüstü öğrencilerinin eğitim programları denildiğinde, ifadelerinde diğer bir ikinci olarak en sik tema olarak "Programa dair $(\mathrm{f}=16, \% 21,3)$ " temasında "eğitim programının amacından ( $\mathrm{f}=5, \% 6,7)$ " ve programlarda yapılan "değişikliklerden ( $\mathrm{f}=3, \% 4)$ " bahsetmişlerdir.

Lisansüstü öğrencilerin eğitim programları denildiğinde üçüncü olarak en sık "Program ögelerine dair ( $\mathrm{f}=14, \% 18,7)$ ” konulardan bahsettikleri görülmüştür. Öğrenciler bu temada en sık "programın ögelerini $(\mathrm{f}=8, \% 10,7)$ " sıralamışlar ve ikinci en sık olarak "ögelerin tanımlarını $(\mathrm{f}=3, \% 4)^{\prime \prime}$ yapmışlardır.

Eğitim programları denildiğinde EPÖ lisansüstü öğrencilerinin "farklı isimlendirmeler ( $\mathrm{f}=8$, $\% 10,7)$ " de yaptıkları ve en çok "rehber-kılavuz $(\mathrm{f}=6, \% 8,0)$ " şeklinde isimlendirmeler kullandıkları görülmüştür. Lisansüstü öğrencilerin "olumsuz ( $\mathrm{f}=2, \% 2,7)$ " ifadeleri de bulunmakta, ancak frekansı oldukça düşüktür.

Lisans üstü öğrencilerinin "eğitim programı" çağrışımlarına dair kendi ifadelerinden bazıları şöyledir:

"Ĕ̆itim programları esasında öğretimi sağlayan öğretmenin ve öğrencilerin içinde bulundukları tüm yaşantıları içine alan bir kavramdır" (G2).

"Ĕgitim programlar denilince aklıma herhangi bir gruba öğretilmesi gereken bir bilginin en iyi ve en etkili şekilde öğretilebilmesi için tasarlanan yol haritası gelmektedir" (G18).

"Ĕ̆itim programı genel olarak okul içinde ya da okul dışında öğrencilerde kazanmasını beklediğimiz yaşantılar düzeneğidir" (G13).

"Ĕ̆itimin bir sistem olarak geliştirilmesini amaçlayan genel bir kavramdır" (G8).

\section{EPÖ Lisansüstü Öğrencilerinin EPÖ Alanı Hakkında Bilgi Düzeyleri ve Yeterlikleri}

Araştırma örnekleminde yer alan EPÖ lisansüstü öğrencilerinin EPÖ alanı hakkında bilgi düzeyleri ve yeterliklerine ilişkin görüşlerinin analiz sonuçlarına dair bulgular Tablo 3'te verilmiştir.

Tablo 3. Lisans Üstü Öğrencilerinin Bilgi Düzeyleri ve Yeterliklerine İlişkin Bulgular

\begin{tabular}{llllll}
\hline No & Tema & Kod & f & $\%$ \\
\hline 1 & Yeterli $(\mathrm{f}=16, \% 53,3)$ & Bilgi düzeyi & 10 & $\% 33,3$ \\
& & Hem bilgi düzeyleri hem uygulama & 4 & $\% 13,3$ \\
& & Uygulama (yeterlik) & 2 & $\% 66,7$ \\
\cline { 3 - 6 } & \multirow{2}{*}{ Yeterli değil (f=11, \%36,7) } & Genel olarak & 7 & $\% 23,3$ \\
& & Kismen yeterli (f=3, \%10) & Uygulama & 4 & $\% 13,3$ \\
\cline { 3 - 6 } & & & 3 & $\% 10,0$ \\
\cline { 3 - 6 } & & & 30 & $\% 100,00$ \\
\hline
\end{tabular}


Tablo 3 incelendiğinde, EPÖ lisansüstü öğrencilerinin EPÖ alanı hakkında bilgi düzeyleri ve yeterliklerine ilişkin görüşleri 3 temada (yeterli, yeterli değil, orta) toplanmakta ve bu temalardaki toplam görüş sayısının 30 olduğu görülmektedir.

Bulgular genel olarak incelendiğinde, EPÖ lisansüstü öğrencilerinin çoğunluğunun EPÖ alanı hakkında bilgi düzeyleri ve yeterliklerine ilişkin kendilerini “yeterli ( $\mathrm{f}=16, \% 53,3)$ " buldukları görülmektedir. Ancak öğrenciler EPÖ alanı hakkında kendilerini daha çok “bilgi düzeyi (f=10, \%33,3)" açısından yeterli görmektedirler. EPÖ lisansüstü öğrencileri ikinci en sık frekansa sahip olan "yeterli değil ( $\mathrm{f}=11, \% 36,7)$ " temasında kendilerini yeterli bulmadıklarına dair görüş belirtmişlerdir. Lisansüstü öğrencileri daha çok EPÖ alanında kendilerini "genel olarak ( $\mathrm{f}=7$, $23,3)$ yeterli bulmadıklarını belirtmişler, ancak "uygulama $(\mathrm{f}=4, \% 13,3)$ " diğer bir deyişle bildiklerini uygulamaya aktarmada da kendilerinin yeterli olmadığına dair görüş de belirtilmiştir. EPÖ lisansüstü öğrencilerinin EPÖ alanında bilgi ve yeterliklerine ilişkin “kısmen yeterli ( $\mathrm{f}=3, \% 10)$ ” düzeyde olduklarını belirten görüşleri de bulunmakta, ancak bu temanın çok düşük frekansa sahip olduğu görülmektedir.

Lisans üstü öğrencilerinin “EPÖ alanında bilgi düzeyleri ve yeterliklerine ilişkin” görüşlerine dair kendi ifadelerinden bazıları şöyledir:

"EPÖ konusunda bilgili fakat alanımda uygulanması konusunda kendimi yeterli görmüyorum" (G12).

"Lisansüstü düzeyde aldı̆̆ımız dersler ve yaptığımız çalışmalar sayesinde alanda araştırmalar yapabileceğimizi ve alandaki konu başlıkları ile ilgili fikir beyan edebileceğimizi düşünüyorum" (G15).

“... pratiğe dönük kısımlarda kendimi yeterli görmüyorum ancak kuramsal boyutta ve araştırma yapma kabiliyeti açısından kendimi yeterli görmekteyim" (G7).

“Dürüst olmak gerekirse; alan hakkındaki bilgi düzeyim ve yeterliliklerim konusunda kendimi \%100 yeterli görmüyorum. Ancak elimden geldiği kadar bu konuda kendimi geliştirmeye devam ediyorum" (G14).

\section{EPÖ Lisansüstü Öğrencilerinin EPÖ Alanında Lisansüstü Yapma Nedenleri}

Araştırma örnekleminde yer alan EPÖ lisansüstü öğrencilerinin EPÖ alanında lisansüstü yapma nedenlerine ilişkin görüşlerinin analiz sonuçlarına dair bulgular Tablo 4 'te verilmiştir.

Tablo 4. EPÖ Lisansüstü Öğrencilerinin EPÖ Alanında Lisansüstü Yapma Nedenleri

\begin{tabular}{lllll}
\hline No & Tema & Kod & $\mathbf{f}$ & \% \\
\hline 1 & Hedeflerine uygun & Öğretmenlik mesleki yeterliğini artırmak/ geliştirmek & 12 & $\% 26,1$ \\
& $(f=32, \% 69,6)$ & Bölümün kapsayıcı olması & 10 & $\% 21,7$ \\
& & Kişisel gelişim & 6 & $\% 13,0$ \\
& & Akademisyen olmak & 4 & $\% 8,7$ \\
\cline { 3 - 6 } & \multirow{2}{*}{ Olanaklar (f=8, \%17,4) } & Lisans alanında imkanların kısıtlı olması & 4 & $\% 8,7$ \\
& & Ulaşım kolaylığı & 3 & $\% 6,5$
\end{tabular}




\begin{tabular}{lllll}
\hline & & Ĕ̆itim özrü ile tayin olmak & 1 & $\% 2,2$ \\
\cline { 3 - 6 } 3 & Bireysel nedenler & İlgi & 4 & $\% 8,7$ \\
& $(\mathrm{f}=5, \% 10,9)$ & Dil yeterliliğin yüksek olması & 1 & $\% 2,2$ \\
\cline { 3 - 6 } 4 & Diğer $(\mathrm{f}=1, \% 2,2)$ & Tavsiye & 1 & $\% 2,2$ \\
\cline { 3 - 6 } & Toplam & 46 & $\% 100$ \\
\hline
\end{tabular}

Tablo 4 incelendiğinde, EPÖ lisansüstü öğrencilerinin EPÖ alanında lisansüstü yapma nedenlerine ilişkin görüşleri 4 temada (hedeflere uygun, olanaklar, bireysel nedenler, diğer) toplanmakta ve bu temaların toplam görüş sayısının 46 olduğu görülmektedir.

Bulgular genel olarak incelendiğinde, EPÖ lisansüstü öğrencilerinin en çok kendi “hedeflerine uygun (f=32, \%69,6)" olduğu için EPÖ alanında lisansüstü yaptıkları görülmektedir. Bu temada lisansüstü öğrenciler öncelikli olarak "öğretmenlik mesleki yeterliğini artırmak/ geliştirmek ( $\mathrm{f}=12, \% 26,1)^{\prime \prime}$ için bu alanda lisansüstü yaptıklarını belirtmişlerdir. Ayrıca öğrenciler için “bölümün kapsayıcı olması ( $\mathrm{f}=10, \% 21,7)$ ” da hedeflerini gerçekleştirmelerinde kolaylık sağladığı için diğer bir neden olarak ve bu temada ikinci sırada belirtilmiştir. EPÖ lisansüstü öğrencileri için "kişisel gelişim ( $\mathrm{f}=6$, \%13)" ve "akademisyen olmak ( $\mathrm{f}=4, \% 8,7)$ " da bu alanda lisansüstü yapma nedenlerinden olduğu görülmektedir.

EPÖ lisansüstü öğrencileri ikinci en sık olarak "lisans alanında imkânların kısıtlı olması (f=4, $\% 8,7)$ " ve "ulaşım kolaylığ $1(\mathrm{f}=3, \% 6,5)$ " gibi “olanaklar $(\mathrm{f}=8, \% 17,4)$ " kaynaklı nedenlerden dolayı EPÖ alanında lisansüstü yaptıklarını belirtmişlerdir. Öğrenciler EPÖ alanında “bireysel nedenler ( $\mathrm{f}=5, \% 10,9)^{\prime \prime}$ kaynaklı lisansüstü yaptıklarını da belirtmişler ancak bu tema frekans olarak üçüncü sırada yer almaktadır. Öğrencilerin bu bireysel nedenler içinde en çok EPÖ alanına "ilgi ( $\mathrm{f}=4, \% 8,7)$ " duydukları için bu alanda lisansüstü yaptıklarını ifade ettikleri dikkat çekmektedir.

EPÖ lisansüstü öğrencilerinin EPÖ alanında lisansüstü yapma nedenlerine ilişkin görüşlerine dair kendi ifadelerinden bazıları şöyledir:

"Herhangi bir alan kısıtlamasına takılmadan çalışmalarımı yürütme imkanına sahip olmak benim için bu alanı tercih etmeme sebep olmuştur" (G16).

"Kişisel bilgi ve becerilerim ile mesleki yeterliliğimi geliştirerek kendime olan özgüvenimi ve özsaygımı artırmak" (G10).

"Söz konusu alanda ilerlemek ve akademisyen olmak" (G3).

"İtiraf etmeliyim ki İngilizce öğretmenliği lisans mezunu bir birey olarak dil bilgimin alanda yükselmemi daha kolaylaştıracă̆ını düşünerek bu alanı seçtim" (G21).

“Öncelikle İngilizce Öğretmenliği mezunu olduğum için kendi alanımda lisansüstü eğitim yapma imkânı çok kısıtlı" (G7).

\section{EPÖ Lisansüstü Öğrencilerinin EPÖ Alanında Lisansüstü Yapmaktan Memnun Olup Olmama Nedenleri}

Araştırma örnekleminde yer alan EPÖ lisansüstü öğrencilerinin EPÖ alanında lisansüstü yapmaktan memnun olup olmama nedenlerine ilişkin görüşlerinin analiz sonuçlarına dair bulgular Tablo 5'te verilmiştir. 
Tablo 5. EPÖ Lisansüstü Öğrencilerinin EPÖ Alanında Lisansüstü Yapmaktan Memnun

Olup Olmama Nedenleri

\begin{tabular}{|c|c|c|c|c|}
\hline No & Tema & Kod & f & $\%$ \\
\hline \multirow[t]{10}{*}{1} & Memnun olma nedenleri & Mesleki gelişim & 14 & $\% 23,7$ \\
\hline & $(\mathrm{f}=43, \% 72,9)$ & Akademik olarak gelişim & 8 & $\% 13,6$ \\
\hline & & Öğrenilenleri uygulama imkânı & 5 & $\% 8,5$ \\
\hline & & Alanın kapsayıcı olması & 5 & $\% 8,5$ \\
\hline & & Programların eğitimin temel noktası olması & 4 & $\% 6,8$ \\
\hline & & Ĕ̆itim sistemine fayda sağlama & 2 & $\% 3,4$ \\
\hline & & Öğretim üyelerinin ilgili olması & 2 & $\% 3,4$ \\
\hline & & Alana ilgili olma & 1 & $\% 1,7$ \\
\hline & & Kaynaklara ulaşım kolaylığı & 1 & $\% 1,7$ \\
\hline & & Alan uzmanlarından ders almak & 1 & $\% 1,7$ \\
\hline \multirow[t]{9}{*}{2} & Memnun olmama nedenleri & Zaman yetersizliği & 2 & $\% 3,4$ \\
\hline & $(\mathrm{f}=11, \% 18,6)$ & Beklentiyi karşılamama & 2 & $\% 3,4$ \\
\hline & & Alanın soyut olması & 1 & $\% 1,7$ \\
\hline & & Alan dışı derslerin olması & 1 & $\% 1,7$ \\
\hline & & Kişisel & 1 & $\% 1,7$ \\
\hline & & Öğretim üyeleri & 1 & $\% 1,7$ \\
\hline & & Bilgi yetersizliği & 1 & $\% 1,7$ \\
\hline & & Çalışmaların uygulamaya yansımaması & 1 & $\% 1,7$ \\
\hline & & Alan dışı öğretim üyelerinden ders almak & 1 & $\% 1,7$ \\
\hline \multirow[t]{3}{*}{3} & Hem memnun hem değil & & 5 & $\% 8,5$ \\
\hline & $(\mathrm{f}=5, \% 8,5)$ & & & \\
\hline & & Toplam & 59 & \%100 \\
\hline
\end{tabular}

Tablo 5 incelendiğinde, EPÖ lisansüstü öğrencilerinin EPÖ alanında lisansüstü yapmaktan memnun olup olmama nedenlerine ilişkin görüşleri 3 temada (memnun olma nedenleri, memnun olmama nedenleri, hem memnun hem değil) toplanmakta ve bu temaların toplam görüş sayısının 59 olduğu görülmektedir.

Bulgular genel olarak incelendiğinde, EPÖ lisansüstü öğrencilerinin büyük oranda $(\% 72,9)$ EPÖ alanında lisansüstü yapmaktan memnun oldukları ve "memnun olma nedenlerini ( $\mathrm{f}=43$, \%72,9)" 10 farklı durumla açıkladıkları görülmektedir. Buna göre EPÖ lisansüstü öğrencileri en çok "mesleki gelişim ( $\mathrm{f}=14, \% 23,7)$ " sağladığ olduklarını ifade etmişlerdir. Öğrencilerin ikinci olarak en çok ifade ettikleri memnun olma nedeni ise "akademik olarak gelişim $(\mathrm{f}=8, \% 13,6)$ " olduğu görülmektedir. “Öğrenilenleri 
uygulama imkânı (f=5, \%8,5)" ve "alanın kapsayıcı olması ( $f=5, \% 8,5)$ " da memnun olma nedenleri arasında en sık sık ifade edilen üçüncü görüş olarak öne çıkmaktadır.

EPÖ lisansüstü öğrencilerinin \%18,6'sının (f=11) EPÖ alanında lisansüstü yapmaktan memnun olmadıkları ve memnun olmama nedenlerini dokuz farklı durumla açıladıkları görülmektedir.

Öğrenciler tarafından “zaman yetersizliği $(\mathrm{f}=2, \% 3,4)$ "ve "beklentiyi karşılamama $(\mathrm{f}=2, \% 3,4)$ " nedenleri bu alanda lisansüstü yapmaktan memnun olmama nedenleri olarak en sık ifade edilen görüşlerdir. Ancak her iki nedenin de ifade sıklığının yüksek olmadığı görülmektedir. Çalışmanın örnekleminde yer alan lisansüstü öğrencilerinden 5 'inin de EPÖ alanında lisansüstü yapmaktan hem memnun hem de memnun olmadıklarına dair görüş belirttikleri görülmektedir.

EPÖ lisansüstü öğrencilerinin EPÖ alanında lisansüstü yapmaktan memnun olup olmama nedenlerine ilişkin görüşlerine dair kendi ifadelerinden bazıları şöyledir:

"Lisans üstü eğitimin bittiğinde bana öğretmenlik yetkinliği anlamında katkı sağlayacă̆ını da düşünüyorum" (G8)"

"Araştırma ruhunu öğrenmek, yerinde saymamak, alanda kendini geliştirmiş akademisyenlerle tanışmak, akademik anlamda ilerlemek" (G3).

"Bildiklerimi uygulamaya dökmek bana bir öğretmen olarak daha yararlı olduğum hissini veriyor" (G19).

"Eğitim programlar ve öğretim alanının eğitim bilimlerinin diğer alanların da nispeten kapsayan bir çatı alan gibi oldŭ̆unu düşünüyorum. Dolayısıyla eğitim programları, öğretmen yetiştirme ve öğretme-öğrenme konularına karşı merakı olan bir birey olarak bu alanda lisansüstü eğitim almaktan memnunum" (G15).

"Ĕğitimime zaman ayırmada zorluk çekiyorum. Aslında en büyük sorun; iş hayatısosyal hayat - aile hayatı gibi kavramlara bağlayarak ve sebep/mazeretler üreterek, eğitime odaklanamamaktır. Burada en bariz hatayı kendimde görüyorum" (G10).

"Hem memnun olduğum hem de olmadığım noktalar mevcut" (G7).

\section{EPÖ Lisansüstü Öğrencilerine Göre EPÖ Alanında Lisansüstü Yapanlarn Yapabileceği Görevler}

Araştırma örnekleminde yer alan EPÖ lisansüstü öğrencilerinin EPÖ alanında lisansüstü yapanların ne tür görevler yapabileceğine ilişkin görüşlerinin analiz sonuçlarına dair bulgular Tablo 6' da verilmiştir.

Tablo 6. EPÖ Alanında Lisansüstü Yapanların Yapabileceği Görevler

\begin{tabular}{lllll}
\hline No & Tema & Kod & f & \% \\
\hline 1 & Görevler & Akademisyen & 14 & $\% 22,2$ \\
& & Program geliştirme uzmanı & 13 & $\% 20,6$ \\
& Bakanlık (MEB) & 10 & $\% 15,9$ \\
& Öğretmenlik & 6 & $\% 9,5$ \\
\hline
\end{tabular}




\begin{tabular}{llc}
\hline Eğitim uzmanı & 5 & $\% 7,9$ \\
Eğitimle ilgili tüm faaliyetleri & 4 & $\% 6,3$ \\
Program değerlendirme uzmanı & 3 & $\% 4,8$ \\
Araştırma & 3 & $\% 4,8$ \\
Ders kitabı inceleme & 2 & $\% 3,2$ \\
Ar-Ge & 1 & $\% 1,6$ \\
Ölçme-değerlendirme uzmanı & 1 & $\% 1,6$ \\
Eğitim politikalarına yön verme & 1 & $\% 1,6$ \\
\hline Toplam & 63 & $\% 100$ \\
\hline
\end{tabular}

Tablo 6 incelendiğinde, EPÖ lisansüstü öğrencilerinin EPÖ alanında lisansüstü yapanların ne tür görevler yapabileceğine ilişkin görüşleri bir temada (görevler) toplanmakta ve bu temanın toplam görüş sayısının 63 olduğu görülmektedir.

EPÖ lisansüstü öğrencileri EPÖ alanında lisansüstü yapanların daha çok “akademisyen ( $\mathrm{f}=14$, $\% 22,2)$ ve "program geliştirme uzmanı ( $\mathrm{f}=13, \% 20,6)$ olarak çalışabileceklerini belirtmişler ve üçüncü en sık belirtilen görüş ise "bakanlık (MEB) $(\mathrm{f}=10, \% 15,9)$ " olarak öne çıkmaktadır. Burada EPÖ lisansüstü öğrencilerinin ifadelerinden anlaşılan MEB'de merkezde bakanlıkta yürütülebilecek görevlerdir. Ayrıca öğrencilerin bu görevleri takiben en sık belirttikleri görüşleri, bu alanda lisansüstü yapanların daha nitelikle bir şekilde "öğretmenlik $(f=6, \% 9,5)$ " yapabileceği ve "eğitim uzmanı $(\mathrm{f}=5, \% 7,9)$ olarak çalışabileceği şeklindedir. EPÖ lisansüstü öğrencileri bu alanda lisansüstü yapanların "eğitimle ilgili tüm faaliyetleri $(\mathrm{f}=4, \% 6,3)$ " yapabileceği şeklinde de görüş belirtmişlerdir. Öğrencilerin görevler temasında daha az belirttikleri görevler ise frekansı yüksek olandan düşük olana doğru "program değerlendirme uzmanı ( $\mathrm{f}=3, \% 4,8)$ ", "araştırma ( $\mathrm{f}=3, \% 4,8)$ ", "ders kitabı inceleme ( $\mathrm{f}=2, \% 3,2)$ ”, "Ar-Ge (f=1, $\% 1,6)$, "ölçme-değerlendirme uzmanı" ( $\mathrm{f}=1, \% 1,6)$ ve "eğitim politikalarına yön verme ( $\mathrm{f}=1$, $\% 1,6)$ şeklindedir.

EPÖ lisansüstü öğrencilerinin EPÖ alanında lisansüstü yapanların ne tür görevler yapabileceğine ilişkin görüşlerine dair kendi ifadelerinden bazıları şöyledir:

“Öğretim üyesi, program geliştirme uzmanı..." (G14).

"Bana milli eğitimin bakanlık teşkilatından taşra teşkilatına kadar her kademede görev yapabilirler" (G4).

"Bu alanda lisansüstü eğitim yapanlar kendi branşlarında öğretmenliklerine daha nitelikli bir şekilde devam edebilir" (G7).

"Eğitime dair her türlü görevi gerçekleştirebileceğimizi düşünüyorum" (G19).

\section{EPÖ Lisansüstü Öğrencilerine Göre EPÖ Alanındaki Araştırma Konuları}

Araştırma örnekleminde yer alan EPÖ lisansüstü öğrencilerinin EPÖ alanındaki araştırma konularının neler olabileceğine ilişkin görüşlerinin analiz sonuçlarına dair bulgular Tablo 7' de verilmiştir.

Tablo 7. EPÖ Alanında Araştırma Konularının Neler Olabileceğine İlişkin Görüşler 


\begin{tabular}{|c|c|c|c|c|}
\hline No & Tema & Kod & $\mathrm{f}$ & $\%$ \\
\hline \multirow[t]{11}{*}{1} & Programlara dair & Program değerlendirme & 11 & $\% 11,2$ \\
\hline & $(\mathrm{f}=39, \% 39,8)$ & Program geliştirme & 11 & $\% 11,2$ \\
\hline & & Ĕ̆itim-öğretim programları & 3 & $\% 3,1$ \\
\hline & & Programın ögeleri & 3 & $\% 3,1$ \\
\hline & & Programları karşılaştırma & 3 & $\% 3,1$ \\
\hline & & Uygulayıcılarla programa dair çalışma & 2 & $\% 2,0$ \\
\hline & & Daha özel alanlar & 2 & $\% 2,0$ \\
\hline & & Öğretim tasarımı & 1 & $\% 1,0$ \\
\hline & & Program değişiklikleri & 1 & $\% 1,0$ \\
\hline & & Program okuryazarlığ & 1 & $\% 1,0$ \\
\hline & & Cumhuriyet dönemi eğitim programları & 1 & $\% 1,0$ \\
\hline \multirow[t]{9}{*}{2} & Öğrenme-öğretmeye dair & Öğretim yöntemleri & 8 & $\% 8,2$ \\
\hline & $(\mathrm{f}=28, \% 28,6)$ & Öğrenen özellikleri & 6 & $\% 6,1$ \\
\hline & & Yeni yaklaşımlar & 4 & $\% 4,1$ \\
\hline & & Öğrenme-öğretme süreci & 4 & $\% 4,1$ \\
\hline & & Öğrenme stilleri & 2 & $\% 2,0$ \\
\hline & & Öğrenme-öğretme kuram ve yaklaşımları & 1 & $\% 1,0$ \\
\hline & & Materyal & 1 & $\% 1,0$ \\
\hline & & Öğrenme stratejileri & 1 & $\% 1,0$ \\
\hline & & Eğitim teknolojileri & 1 & $\% 1,0$ \\
\hline \multirow[t]{2}{*}{3} & Öğretmenlere dair & Öğretmen yetiştirme & 9 & $\% 9,2$ \\
\hline & $(\mathrm{f}=14, \% 14,3)$ & Öğretmenlerin mesleki gelişimi & 5 & $\% 5,1$ \\
\hline \multirow[t]{7}{*}{4} & Diğger & Eğitimle ilgili tüm konular & 4 & $\% 4,1$ \\
\hline & $(\mathrm{f}=12, \% 12,2)$ & Sınıf yönetimi & 2 & $\% 2,0$ \\
\hline & & Eğitim felsefesi & 2 & $\% 2,0$ \\
\hline & & EP ve eğitim yönetimi ilişkisi & 1 & $\% 1,0$ \\
\hline & & Yaygın eğitim & 1 & $\% 1,0$ \\
\hline & & Okul & 1 & $\% 1,0$ \\
\hline & & Okul içi ve dışı etkinlikler & 1 & $\% 1,0$ \\
\hline \multirow[t]{4}{*}{5} & Değerlendirmeye dair & Başarı & 3 & $\% 3,1$ \\
\hline & $(\mathrm{f}=5, \% 5,1)$ & Mevcut durum & 1 & $\% 1,0$ \\
\hline & & Ölçme değerlendirme & 1 & $\% 1,0$ \\
\hline & & Toplam & 98 & $\% 100$ \\
\hline
\end{tabular}


Tablo 7 incelendiğinde, EPÖ lisansüstü öğrencilerinin EPÖ alanında araştırma konularının neler olabileceğine ilişkin görüşleri 5 temada (Programlar, Öğrenme-öğretme, Öğretmen, Diğer, Değerlendirme) toplanmakta ve bu temaların toplam görüş sayısının 98 olduğu görülmektedir.

Bulgular genel olarak incelendiğinde, EPÖ lisansüstü öğrencilerinin EPÖ alanında araştırma konusu olarak daha çok "programlara dair ( $(\mathrm{f}=39, \% 39,8)$ " konuları ifade ettikleri ve bu temada 11 farklı konudan bahsettikleri görülmektedir. Bu temada en çok öne çıkan iki araştırma konusunun "program değerlendirme $(\mathfrak{f}=11, \% 11,2)$ " ve "program geliştirme $(\mathfrak{f}=11, \% 11,2)$ " olduğu görülmektedir. İkinci en sık belirtilen araştırma konuları ise "eğitim-öğretim programları $(\mathrm{f}=3, \% 3,1)$, "programın ögeleri $(\mathrm{f}=3, \% 3,1)$ " ve "programları karşılaştırma ( $\mathrm{f}=3$, $\% 3,1)$ olduğu görülmektedir.

EPÖ lisansüstü öğrencilerinin EPÖ alanında araştırma konusu olarak ifade ettikleri ikinci en sık frekansa sahip tema ise Öğrenme-öğretmeye dair ( $\mathrm{f}=28, \% 28,6)$ " konuları içermektedir. Bu temada "Öğretim yöntemleri (f=8, \%8,2)”, “Öğrenen özellikleri ( $\mathrm{f}=6, \% 6,1)$ ”, “Yeni yaklaşımlar $(\mathrm{f}=4, \% 4,1)$ ve “Öğrenme-öğretme süreci $(\mathrm{f}=4, \% 4,1)$ " konuları sırasıyla en sık belirtilen konular olarak öne çıkmaktadır.

EPÖ lisansüstü öğrencilerinin EPÖ alanında araştırma konusu olarak “Öğretmenlere dair $(\mathrm{f}=14, \% 14,3)^{\prime \prime}$ konuları üçünü sırada en sık olarak ifade ettikleri görülmektedir. Bu temada, EPÖ alanında “Öğretmen yetiştirme (f=9, \%9,2)" ve "Öğretmenlerin mesleki gelişimi (f=5, \%5,1)" konularının çalışılabilecek konular olduğunu ifade etmişlerdir. EPÖ lisansüstü öğrencilerinin "Öğretmenlerin mesleki gelişimi” ile ifade etmek istedikleri, öğretmenlerin hizmet içinde gelişim süreçleridir.

EPÖ lisansüstü öğrencilerinin EPÖ alanında araştırma konusu olarak ifade ettikleri dördüncü en sık frekansa sahip tema ise "diğer $(\mathrm{f}=12, \% 12,2)$ " konuları içermektedir. Ancak bu temada belirtilen konuların frekanslarının çok düşük olduğu görülmektedir. "Diğer" konular içinde en sık belirtilen konunun "eğitimle ilgili tüm konular ( $\mathrm{f}=4, \% 4,1)$ " olduğu görülmektedir.

EPÖ lisans üstü öğrencilerinin EPÖ alanında araştırma konusu olarak bahsettikleri en az frekansa sahip temanın "değerlendirmeye dair $(\mathrm{f}=5, \% 5,1)$ " konuları içeren tema olduğu görülmektedir. Bu temada "başarı (f=3, \%3,1) konusunun öne çıtı̆̆g görülmektedir.

EPÖ lisansüstü öğrencilerinin EPÖ alanında lisansüstü yapanların ne tür görevler yapabileceğine ilişkin görüşlerine dair kendi ifadelerinden bazıları şöyledir:

"Bu alandaki akademisyenler eğitim programı geliştirme, eğitim programları değerlendirme, öğrenme-öğretme kuram ve yaklaşımları, öğretim tasarımı, öğrenme stilleri, çă̆daş öğrenme kuramlar gibi konularda araştırma yapabilirler diye düşünüyorum" (G6).

"Ĕ̆̈itim programlarının geliştirilmesi ve değgerlendirilmesine yönelik tüm çabalar, çeşitli öğretim yöntemlerinin etkililiğinin belirlenmesi, öğretmen yetiştirme sistemi, öğrenmeyi veya başarıyı etkileyen öğrenen özellikleri, öğrencinin değerlendirilmesi gibi konular çalışılabilir" (G7).

"Bu alanda son yıllarda dikkat çeken proje tabanl, probleme dayal, beyin temelli, harmanlanmış ya da kuantum öğrenme gibi öğrenme türleri, eleştirel düşünme, 
problem çözme ya da öz yeterlik gibi öğretmen- öğrenci özellikleri, öğrenme stratejileri ve stilleri ya da program değerlendirmeleri çalışma alanı olarak seçilebilir" (G12).

"Bu alanda eğitim ve öğretimi ilgilendiren her konu eğitim programcısı için araştırma konusudur" (G13).

"Eğitimde yeni trendler, yeni öğretim teknolojileri, yeni yöntem ve teknikler, eğitim ve programdan kaynakl problemler ve çözüm önerileri, felsefi akımlar, ölçme ve değerlendirme süreçleri ve yenilikçi ölçme değerlendirme araçları ve daha birçok konuda araştırma yapabilirler" (G17).

\section{Tartışma ve Sonuç}

Bu bölümde araştırmanın bulgularına dayalı sonuçlar ve tartışmalara yer verilmiştir. Aşağıda Şekil 1'de EPÖ lisansüstü öğrencilerinin EPÖ alanına ilişkin algılarına dair kod bulutu verilmiştir. Kod bulutu yapılan analiz sonucu oluşturulan temalardaki kodların ifade sıklığına göre şekillenmiştir. İfade sıklığı ve punto büyüklüğü doğru orantılı olarak kod bulutu ortaya çıkmaktadır. Kod bulutunun yapılan analizin özeti ve sonucu olduğu da söylenebilir.

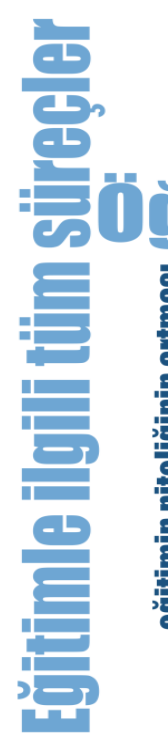

\section{program değerlendirme

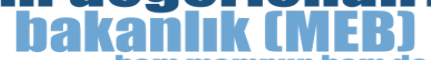
henil mennum hem deŭ

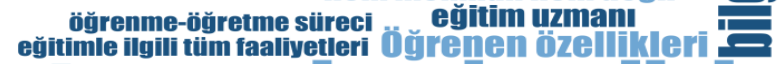

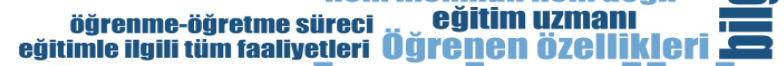
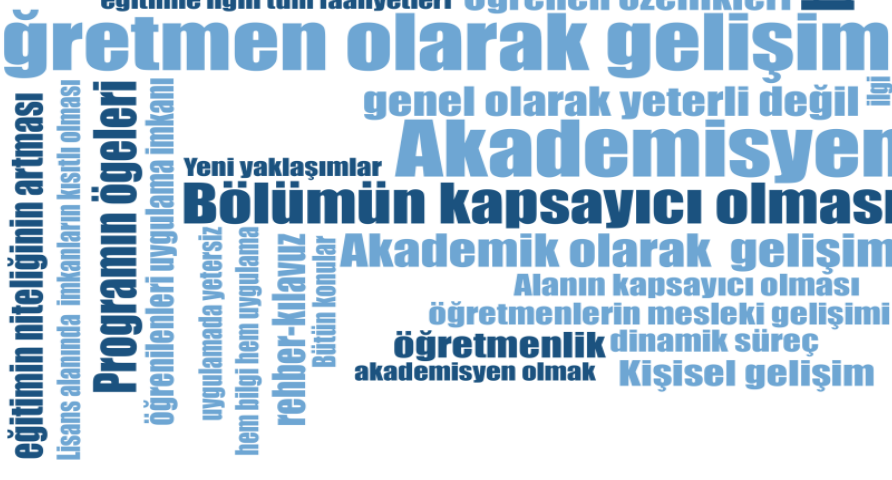
genel olarak yeterli değil

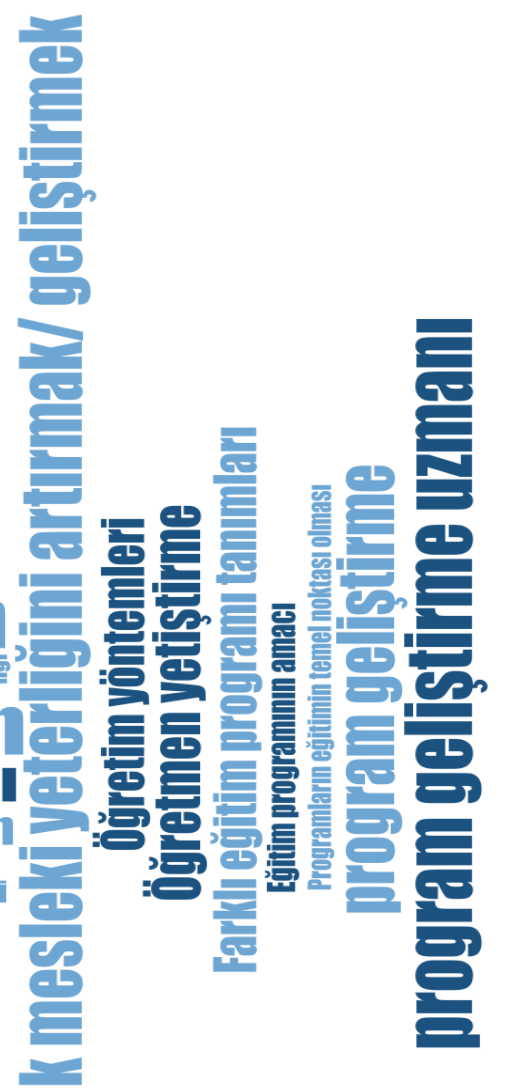

Şekil 1. EPÖ lisansüstü öğrencilerinin EPÖ alanına ilişkin algılarına dair kod bulutu 
EPÖ alanında öğrenim gören lisansüstü öğrencileri eğitim programları denildiğinde, EPÖ alanının kapsamını dinamik, ayrıntılı ve sistematik süreç, eğitimle ilgili tüm süreçler, program ögeleri olarak ifade etmektedirler. Bu kapsamın tamamına program okuryazarlığ 1 denilebilir. Birçok bileşeni olan okuryazarlık üç temada toplanabilmektedir: Bilgi, beceri, tutum. Bu üç ana temanın programa uygulanmasında bileşenler şu şekilde oluşmaktadır: program bilgisi (kavramlar, felsefe), becerisi (program hazırlama, uygulama, rehberlik, izleme, değerlendirme, yönetme becerileri) ve tutum (destek, yardım, ihtiyaçları karşılama, açıklama) şeklindedir (Yar Yıldırım, 2018).

Araştırma sonuçları incelendiğinde, öğrencilerin yeterlilik konusunda özellikle kendilerini bilgi olarak yeterli gördüklerini vurguladıkları görülmektedir. Ancak genel olarak ve uygulamada yeterli bulmadıkları görülmektedir. Bilimsel yöntemi araştırmalarda kullanma konusunda yeterlilik sorunu yaşadıkları dikkat çekmektedir. Karaman ve Bakırcı (2010), lisansüstü öğrencilerin bilgi paylaşımı sağlayan kongre, sempozyum ve benzeri bilimsel toplantılara yeterince katılamamasının kendi kişisel ve profesyonel gelişimleri açısından bir eksiklik oluşturmakta olduğunu, bu sebeple bu tür öğrenme ortamlarına katılımlarının desteklenmesi gerektiğini belirtmektedir. Ayrıca EPÖ bölümündeki öğretim üyeleri de yüksek lisans öğrencilerini eğitim bilimleri altyapısı konusunda yetersiz olarak değerlendirmektedirler (Gözütok, Alkın ve Ulubey, 2010).

Araştırmaya katılan EPÖ lisansüstü öğrencileri bu alanda lisansüstü yapma nedenlerini daha çok kendi belirledikleri hedefler üzerinden açıklamışlardır. Buna göre öne çıkan nedenlerin öğretmenlik mesleki yeterliğini artırmak/ geliştirmek, bölümün kapsayıcı olması, kişisel gelişim ve akademisyen olmak gibi nedenler olduğu görülmektedir. Bu sonuç Alabaş, Kamer ve Polat'ın (2012) araştırmaya katılan öğrenciler lisansüstü eğitimi kişisel gelişim, mesleki kariyer ve akademik personel olma olarak değerlendirmekte sonucuyla örtüşmektedir. Araştırmaya katılanlar lisansüstü program için ulaşım ve erişimin öneminden söz etmektedirler. Bu konu Dünya ülkelerinde de önemli bir konu olduğu görülmektedir (Johnson, 2009, s. 13-19).

Öğrenilenleri uygulama imkânı lisansüstü programda öğrendiklerini uygulamaya, özellikle öğretmenliğe taşıdıklarını ifade etmektedirler. Bu sonuçla EPÖ Bologna sürecinde öğrenciler bu programı başarıyla bitirdikleri takdirde öğrendiklerini uygulayabilecektir diye söz edilen bir yeterlik arasında ilişki görülmektedir (www.ksu.edu.tr). Bu açıdan EPÖ lisansüstü programlarının uygulamaya katkısı ortadadır. Ayrıca öğrencilerin lisansüstü görme nedenleri arasında en çok belirttikleri durum, öğretmenlik mesleki yeterliklerini artırmaktır. Öğrencilerin EPÖ alanında lisansüstü yapmaktan öğretmen olarak geliştikleri için memnun olmaları da bu durumu desteklemektedir. Araştırmaya katılanların görüşleri incelendiğinde sadece öğretmen olarak değil, lisansüstü eğitimin kendilerini akademik olarak geliştiklerini de ifade etmektedirler. Bu sonuç Karaman ve Bakırcı'nın (2010) araştırmasında sonucuyla da örtüşmektedir. Buna göre daha kapsamlı bilimsel araştırmalar yapma, karmaşık problemleri çözebilme, mesleki alanlarda uzmanlaşma, bilgi üretebilme ve sentez yapabilme lisansüstü öğrenimin amaçları arasındadır.

Araştırmada öğrenciler kuramı uygulamaya taşıyabildiklerini ifade etmektedirler. Başer, Narlı ve Günhan'ın (2005) araştırmasında da öğretmenlerin büyük çoğunluğunun lisansüstü eğitimde teoriyi uyulamaya taşıyabildikleri görülmektedir. Bu sonucu destekleyen başka bir araştırmada ise (Özdem, Bülbül ve Güngör, 2002) okul müdürleri eğitim süreçlerinde gördükleri teorik bilgileri uygulamada pratiğe döktüklerini ifade etmektedirler. Ancak 
Karakütük (2000) ve Doğusan (2003) lisansüstü eğitimin Türk Milli Eğitim Sistemine bu katkısının yeterince görülmediğini, lisansüstü programların özendirilmediğini, ilgili mevzuatın yetersiz olduğunu ifade etmektedirler.

Araştırma sonucunda lisansüstü zaman yetersizliği ve programın beklentiyi karşılamaması gibi sebeplerden alanda lisansüstü yapmaktan memnun olmadıklarını ifade etmişlerdir. Abiddin ve İsmail' in (2011) araştırmasına göre lisansüstü eğitim gören öğrencilerin bir yandan çalıştıkları, bir yandan aileleriyle ilgilenmeleri, yeterli bilgilendirme yapılmaması yüzünden eğitimi ya yarıda bırakmakta ya da eğitim uzamaktadır. Bu araştırmayı destekleyen bir başka araştırma Kayıkçı ve Ercan (2013) tarafından yapılmıştır. Araştırma sonucunda öğrenciler tayin, öğretim üyelerinin ilgisizliği ve ailesel nedenlere bağlı olarak eğitimlerini yarıda bırakmışlardır. Ayrıca başka bir araştırmada katılımcıların araştırma kapsamında ortaya çıkan hemen hemen bütün sorun alanlarındaki eksikliklerin giderilmesi konusunda öğretim üyelerinden büyük bir beklenti içinde oldukları saptanmıştır (Sezgin, Kavgacı ve Kılınç, 2011). Güven, Kerem ve Ersoy'un (2007) araştırmalarında lisansüstü öğrenciler için, derslerin içeriklerinin, akademisyen yeterliklerinin, akademisyenlerle öğrenciler arasında sağlıklı iletişimin ve akademisyenlerin danışmanlık yeterliklerinin çok önemli olduğunu belirtmektedirler. Bu sonucun da beklentiyle ilgili olduğu görülmektedir.

Araştırmaya katılanlar EPÖ lisansüstü programından mezun olduktan sonra çalışma alanı olarak en çok akademisyenliği belirtmektedirler. Başka araştırmalar da (Karaman ve Bakırcı, 2010; Turhan ve Yaraş, 2013) lisansüstü eğitimin en önemli amacının uzmanlaşma ve akademik kariyer olduğunu ortaya koymaktadır. Türkiye'de yükseköğretimde gelinen noktaya bakıldığında birçok alanda ihtiyaç duyulandan daha az sayıda yüksek lisans ve doktora mezunu olmasının yanında (Doğan, Koyuncu, Gökdemir ve Kahveci, 2016) bazı alanlarda yeterli akademisyen bulunmaktadır. Bu alanlardan birisi de eğitim bilimleri alanındadır. Türkiye' de halen 394174 yüksek lisans öğrencisi, 96199 doktora öğrencisi olduğu görülmektedir. YÖK verilerine göre de EPÖ alanında çalışan akademisyen sayısının 689 olduğu görülmektedir (www. yok.gov.tr). EPÖ lisansüstü öğrencileri, bu alanda lisansüstü sonrası çalışma alanı olarak akademisyenliğin dışında en çok program geliştirme uzmanı, bakanlık ve öğretmenlik gibi görevleri öncelikli olarak belirtmişlerdir.

Görüşleri alınan EPÖ lisansüstü öğrencilerine göre EPÖ alanında araştırma konularının, programlar, öğrenme-öğretme, öğretmen, diğer, değerlendirme olduğu görülmektedir. EPÖ alanının yapısal öğeleri incelendiğinde, eğitim teknolojisi, eğimin sosyolojisi, tarihi temelleri, güzel sanatları da içerdiği görülmektedir (Bıkmaz vd.2013). EPÖ alanında yapılan doktora tezlerinin ağırlıklı olarak, yöntem, teknik, öğretme-öğrenme yaklaşımları, öğretmen eğitimi, örgün eğitim programlarının etkililiğii, değerlendirmesi konularını içerdiği görülmektedir (Bıkmaz vd. 2013). Saracaloğlu ve Dursun'un (2010) araştırmasında EPÖ alanındaki tezlerde "ders programları", "öğrenme yaklaşımları", "bilgisayar ve teknoloji”, "öğrenme stilleri" ve "öğrenme stratejileri” ile ilgili konuların çalışıldığı görülmüştür. Benzer şekilde başka bir araştırmada (Ozan ve Köse, 2014) EPÖ alanında yapılan makalelerin yarıdan fazlasının öğrenme, öğretme, öğrenci-öğretmen özellikleri, öğretmen yetiştirme ve program değerlendirme konu alanlarında yapıldığı görülmüştür. Gömleksiz ve Bozpolat (2013), EPÖ alanındaki lisansüstü araştırma konusu olarak alana katkı sağlayacak işlevsel konuların seçimine dikkat edilmesi gerektiğini belirtmektedir.

Araştırmanın sonuçları doğrultusunda aşağıdaki öneriler geliştirilebilir: 
a. EPÖ lisansüstü eğitim alanı eğitimin tüm süreçlerini kapsamaktadır. Bu da alan bilgisi konusunda birtakım sorunlar oluşturabilmektedir. EPÖ alanının lisansta yoğunluğu daha da artırabilir.

b. EPÖ lisansüstü eğitim alanında araştırma konularının da kapsamı oldukça geniş görülmektedir. Araştırma konularının programın değişkenleri olması ve işlevselliği konularında farkındalık oluşturulabilir.

c. EPÖ alanında lisansüstü yapmanın uygulamaya katkı sağlaması düşünüldüğünde Türk Eğitim Sistemi'nin niteliğinin artırılması adına öğretmenlerin tezli, tezsiz, uzaktan lisansüstü eğitim yapmaları teşvik edilebilir ve desteklenebilir.

d. Uygulamaya yansıma açısından EPÖ lisansüstü eğitim yapanlarla yapmayanların program okuryazarlık düzeyleri ve uygulamadaki farklılıklar araştırılabilir.

\section{Kaynakça}

Abiddin, N. Z., \& Ismail, A. (2011). Attrition and completion issues in postgraduate studies for student development. International Review of Social Sciences and Humanities, 1(1), 15-99.

Alabaş, R., Kamer, T., \& Polat, Ü. (2012). Öğretmenlerin kariyer gelişimlerinde lisansüstü eğitim: Tercih sebepleri ve süreçte karşılaştıkları sorunlar. E International Journal of Educational Research, 3(4), 89-107.

Baltacı, A. (2018). Nitel araştırmalarda örnekleme yöntemleri ve örnek hacmi sorunsalı üzerine kavramsal bir inceleme. BEÜ SBE Dergisi, 7(1), 231-274.

Başer, N., Narlı, S., \& Günhan, B. (2005). Öğretmenlerin lisansüstü eğitim alanlarında yaşanan sorunlar ve çözüm önerileri. Dokuz Eylül Üniversitesi Buca Ĕ̆itim Fakültesi Dergisi, 1, 129135.

Bıkmaz, F., Aksoy, E., Tatar, Ö., \& Atak A. C. (2013). Eğitim programları ve öğretim alanında yapılan doktora tezlerine ait içerik çözümlemesi (1974-2009). Ĕ̆itim ve Bilim, 38(168), 288303.

Burgaz, B., \& Şentürk, İ. (2007). Yüksek lisans tez danışmanlarının iletişim davranışlarına ilişkin danışman ve danışan görüşleri. III. Lisansüstü Eğitim Sempozyumu Bildiri Kitabı,133-144.

Bülbül, T. (2003). Ankara Üniversitesi Eğitim Fakültesinde görev yapan öğretim üyelerinin lisansüstü öğretime öğrenci seçme sürecine ilişkin görüşleri. Ankara Üniversitesi Eğitim Fakültesi Dergisi, 36, 1-2.

Çakar, Ö. (2001). Türkiye bilimler akademisi: Bilim adamı yetiştirme lisansüstü eğitim. Ankara: TÜBİTAK.

Demirel, Ö. (2005). Eğitimde program geliştirme: Kuramdan uygulamaya (8. Baskı). Ankara: Pegem.

Doğan, N., Koyuncu, İ., Gökdemir, P., \& Kahveci, M. (2016). Öğrencilerin eğitim bilimleri enstitüsü lisansüstü programlarına kabul durumlarının yordanması. Hacettepe Üniversitesi Eğitim Bilimleri Enstitüsü Eğitim Araştırmaları Dergisi, 2(2), 114-131. 
Doğusan, F. (2003). İlköğretim okulu yönetici ve öğretmenlerinin öğretmenlerin lisansüstü öğrenimi konusundaki tutumları (Yayımlanmamış Yüksek Lisans Tezi). Kırıkkale Üniversitesi, Sosyal Bilimler Enstitüsü, Kırıkkale.

Duan, X., \& Shan, G. (2013). Suggestions for graduate curriculum reform. In Proceedings of AASRI Winter International Conference on Engineering and Technology (AASRI-WIET 2013), December 28-29, 2013, Saipan, USA, 202-203.

Erişti, B. (2013). Türk üniversitelerinde eğitim programları ve öğretim anabilim dalında görev yapan öğretim elemanlarının profilleri. Eğitim ve Bilim, 38(167), 312-326.

Gömleksiz, M. N., \& Bozpolat, E. (2013). Eğitim programları ve öğretim alanındaki lisansüstü tezlerin değerlendirilmesi. The Journal of Academic Social Science Studies, 6(7), 457-472.

Gömleksiz, M. N., \& Et, S. Z. (2013). Öğretmen adaylarının lisansüstü eğitime ilişkin metaforik algıları. VI. Ulusal Lisansüstü Eğitim Sempozyumu, 145152.

Gözütok, D., Alkın, S., \& Ulubey, Ö. (2010). Eğitim programları ve öğretim alanının amaçlarının gerçekleştirilmesini etkileyen sorunların belirlenmesi. Ulusal Eğitim Programları ve Öğretim Kongresi, Balıkesir.

Gültekin, M. (2013). İlköğretim öğretmen adaylarının eğitim programı kavramına yükledikleri metaforlar. Eğitim ve Bilim, 38(169), 126-141.

Gültekin, M., \& Dal, S. (2007). Sınıf öğretmenliği doktora programı mezunu öğrencilerin sınıf öğretmenliği doktora programına ilişkin görüşleri. III. Lisansüstü Eğitim Sempozyumu Bildiri Kitabı, 275-286.

Güven, B., Kerem, E. A., \& Ersoy, E. (2007). Lisansüstü eğitim sırasında karşılaşılan sorunlara ilişkin öğrenci görüşlerinin belirlenmesi. III. Lisansüstü Eğitim Sempozyumu Bildiri Kitabı, 308-318.

IBE-International Bureau of Education. (1998). Curriculum Development. Educational Innovation and Information, 97.

İşcan, C. D., \& Bıkmaz, F. H. (2012). Eğitim programları ve öğretim alanında lisansüstü eğitim programlarının analizi. Ankara Üniversitesi Ĕ̆itim Bilimleri Fakültesi Dergisi, 45(1), 107-138.

Johnson, J. M. (2009). Avrupa, Asya ve Amerika'da lisansüstü öğretim reformu ve bilim insanları ile mühendislerin uluslararası hareketliliği. NSF (National Science Foundation) Çalıştayı Bildirileri (K. Karakütük, Çev. Ed). Ankara: Pegem.

Karakütük, K. (2000). Öğretmenlerin lisansüstü öğretimi konusunda yönetici ve öğretmenlerin görüşleri. Buca Eğitim Fakültesi Dergisi, 12(2000), 193-209.

Karakütük, K. (2001). Öğretim üyesi ve bilim insanı yetiştirme: Lisansüstü öğretimin planlanması. Ankara: Anı.

Karaman, S., \& Bakırcı, F. (2010). Türkiye'de lisansüstü eğitim: Sorunlar ve çözüm önerileri. Gaziosmanpaşa Üniversitesi Sosyal Bilimler Araştırmaları Dergisi, 5(2), 94-114.

Kayıkçı, K., \& Ercan, B (2013). The evaluation of educational administration and supervision graduate programs in Turkey: A case study. International Journal of Educational Research, 4(3), 74-94. 
Korkmaz, İ. (2007). Eğitim programı: Tasarımı ve geliştirilmesi. A. Doğanay (Ed.), Öğretim ilke ve yöntemleri içinde (2. bs., s. 2-34). Ankara: Pegem.

Lisansüstü Eğitim ve Öğretim Yönetmeliği. (2016). Resmî Gazete Tarihi: 20.04.2016 Resmî Gazete Sayıst: 29690.

Myers, B. E., \& Dyer, J. E. (2003). Advising components, roles, and perceived level of competence of university faculty. Journal of Southern Agricultural Education Research, 53(1), 258-271.

Ozan, C., \& Köse, E. (2014). Eğitim programları ve öğretim alanındaki araştırma eğilimleri. Sakarya University Journal of Education, 4(1), 116-136.

Özdem G., Bülbül, T., \& Güngör, S. (2002). Eğitim Yönetimi Planlaması Teftişi ve Ekonomisi Anabilim Dalı Tezsiz Yüksek Lisans Programına Devam Eden Öğretmen ve Okul Yöneticilerinin Programa ilişkin Görüşlerinin Değerlendirilmesi, 21. yüzyıl Eğitim Yöneticilerinin Yetiştirilmesi Sempozyumu, Ankara: Ankara Üniversitesi Basımevi, 165177.

Özdemir, S. M. (2009). Eğitimde program değerlendirme ve Türkiye'de eğitim programlarını değerlendirme çalışmalarının incelenmesi. Yüzüncü Yıl Üniversitesi Ĕ̆gitim Fakültesi Dergisi, 6(2), 126-149.

Sağlam, M. (2007). Lisanüstü Eğitim Modelleri. Anadolu Üniversitesi Eğitim Bilimleri Enstitüsü Lisansüstü Eğitim Sempozyumu: Lisansüstü Eğitimde Sorunlar ve Çözüm Önerileri (17-20 Ekim 2007) (s. 1-12).

Saracaloğlu, A. S., \& Dursun, F. (2010). Türkiye' de Eğitim Programları ve Öğretim Alanındaki Lisansüstü Tezlerinin İncelenmesi. 1. Ulusal Eğitim Programları ve Öğretim Kongresi, Balıkesir Üniversitesi, Ayvalık.

Saylor, J. G., Alexander, W. M., \& Lewis, A. J. (1981). Curriculum planning for better teaching and learning. New York: Holt, Rinehart and Winston.

Sezgin, F., Kavgacı, H., \& Kılınç, A. Ç. (2011). Türkiye'de eğitim yönetimi ve denetimi lisansüstü öğrencilerinin öz değerlendirmeleri. Yükseköğretim ve Bilim Dergisi, 1(3), 161-169.

Turhan, M., \& Yaraş, Z. (2013). Lisansüstü programların öğretmen, yönetici ve denetmenlerin mesleki gelişimine katkısı. Elektronik Sosyal Bilimler Dergisi, 12(43), 200-218.

www.ksu.edu.tr. Erişim tarihi: 03.05.2020.

www.yok.gov.tr. Erișim tarihi: 03.05.2020

Yar Yıldırım, V. (2018). Okul yöneticilerinin program okuryazarlıklarına yönelik bir hizmet içi eğitim programının geliştirilmesi ve değerlendirilmesi (Yayınlanmamış doktora tezi). Gaziosmanpaşa Üniversitesi, Eğitim Bilimleri Enstitüsü, Tokat.

Yıldırım, A., \& Şimşek, H. (2011). Sosyal bilimlerde nitel araştırma yöntemleri. Ankara: Seçkin. 